\title{
The study of 3Rs - Reuse, Repair, and Redesign at Swedish recycling mall
}

\author{
DOI: 10.35530/IT.070.06.1554
}

MANOJ KUMAR PARAS
LARS HEDEGÅRD
ANTONELA CURTEZA

\author{
RUDRAJEET PAL \\ YAN CHEN \\ LICHUAN WANG
}

\section{ABSTRACT - REZUMAT}

The study of 3Rs - Reuse, Repair, and Redesign at Swedish recycling mall

The shopping mall concept has emerged to provide unique mall facets to satisfy consumers that search for the ultimate shopping experience. Under one roof different sellers are assembled together with food outlets and entertainment to fulfill the requirements of consumers. Gradually an awareness of over-consumption has risen together which calls for reuse activities that reduce the consumption of new products. As an answer to the concept of a mall for sustainable practice, a recycling mall has been developed in Eskilstuna, Sweden. This study has been undertaken to understand the practice of the recycling mall and its encompassing reverse value chain activities. This is primarily done in two phases i.e., first to understand the backend operations by visiting collecting and sorting facilities and secondly to comprehend the perspectives of the management team by interviewing them. The findings from the current study suggest that the unique concept of recycling mall create a positive awareness among the customers to reuse, repair and redesign used products. An individual gets a unique experience to donate and purchase clothes, sports equipment, and construction material under one roof.

Keywords: upcycling, redesign, reuse, repair, clothes

\section{Studiul celor 3R - Reutilizare, Reparare și Reproiectare în centrele de recilare din Suedia}

Conceptul de centru pentru cumpărături a apărut pentru a oferi aspecte unice cu scopul de a satisface consumatorii care caută experiența de cumpărături de cea mai bună calitate. Sub același acoperiș, diferiți comercianți sunt grupați cu magazinele alimentare și de divertisment pentru a satisface cerințele consumatorilor. Treptat, a crescut conștientizarea în ceea ce privește supraconsumul, ceea ce necesită activități de reutilizare, care reduc consumul de produse noi. Ca răspuns la conceptul de centru pentru o practică durabilă, un centru de reciclare a fost dezvoltat în Eskilstuna, Suedia. Acest studiu a fost întreprins pentru a înțelege practicile centrului de reciclare și ale activităților sale din lanțul valoric invers. Acesta se realizează în două faze, în primul rând pentru a înțelege operațiunile de backend vizitând unitățile de colectare și sortare și în al doilea rând pentru a înțelege perspectivele echipei de management, prin intervievarea acesteia. Rezultatele studiului sugerează că acest concept de centru de reciclare creează o conștientizare pozitivă a clienților de a reutiliza, repara și reproiecta produsele folosite. O persoană dobândește o experiență unică prin donarea și achiziționarea articolelor de îmbrăcăminte, echipamentelor sportive și materialelor de construcție sub un singur acoperiș.

Cuvinte-cheie: reciclare, reproiectare, reutilizare, reparare, articole de îmbrăcăminte

\section{INTRODUCTION}

Reuse is considered to be one of the most common ways to achieve sustainability in the clothing value chain [1]. 'Reuse' is a process to extend the life of a clothing product by acquiring the products after the end of use or end of life [2]. The reuse can minimize the entry of new products and thus, reduce the environmental impacts [3-4]. The products which are not suitable for direct reuse can be recycled to extract fibres or transformed into rags, wipers, and insulating material [5-9]. The reuse based clothing value chain consists of collection, sorting, and reprocessing. The collection is a process to acquire an end of use or end of life products, whereas sorting and grading operation involves categorization of acquired products according to their condition $[5,7,10]$. The sorted and graded products can be reprocessed such as repair, redesign [11] and washed to improve the aesthetic and/or functional value [7].

Informal exchange of clothes is an old phenomenon between friends and family, however, a formal model has been designed to recover used products[12]. In most of Western Europe and North American countries, the used clothes collection is carried out by charities [13]; whereas the collection of paper, plastic, and glass is performed by the for-profit organization [3]. The collection channel driven by the producer is better than the third party collector [14]. Easy accessibility to collection sites such as near city centre, gas station, housing area is significantly important for consumers to discard useful products for reuse [15-18]. Sorting is the categorization process to provide acquired products with a different path such as direct reuse, recycle or waste stream for the incineration [19]. The used clothes are fractioned into 
superior quality for the domestic market, inferior quality for export, and unwearable quality to repurposed into rags and wipers [5]. The sorting and categorization process for textile and clothing is complex due to the enormous variance of fabric material and its construction into clothes $[5,8]$. The sorting process can be optimized by removal of waste and unwanted products from reverse value chain [20]. This can be achieved by concurrent collection and sorting process [21]. The cost efficiency in sorting process can be achieved by offshoring sorting and grading activities to the developing countries. The functional and aesthetic value of products can be restored or improved by repair, redesign and laundry activities [1, 22-23]. The skill and technical knowledge influence the reprocessing activities [5, 7]. The recycling mall strategy to promote the reuse, repair, and redesign is novel. The purpose of this paper is to understand the management of unique concept of recycling mall based on the reuse-based reverse value chain.

\section{METHOD}

The qualitative method was adopted to perform the research considering its relevance and appropriateness to study inter-organizational relationships. The phenomena of reuse, repair, and recycling of used clothes have been studied at the Swedish recycling mall. Through telephonic discussion and exchange of emails, researchers have able to establish a relationship with mall manager. This provided better access and participation of organization in the research process. Access to personnel and facilities of an organization improved quality of data. Data has been collected from multiple sources within the firm [24].

Data collection for this research has started by reading newspaper articles, reports to understand the unique phenomena of recycling mall. Prior to the visit to the recycling mall, websites of the mall and news reports available on different websites were thoroughly explored. During the visit, in-depth face to face interview was carried out with the mall manager. The interview lasted for more than one hour. The researcher has made a visit to different sections of the mall. Direct observation helped us to understand the process in details. Mall manager guided around different processes involved. One of the researchers is a native speaker of the language spoken by the employee of the recycling mall. This helps us to collect minute information perfectly from various persons in the organization. Follow up interviews were undertaken to strengthen the analysis. During the analysis phase, different logical tools like table, charts and figure were made to understand the trends and phenomena. NVivo 10 was used to analyze the interviews and other collected information. Interviews transcript were systematically analyzed to find out themes, ideas, patterns, concepts to understand the process of recycling mall [25].

\section{FINDINGS}

The Recycling mall is Sweden's - and perhaps the world's - first shopping centre with shops that give used things new life by repairing, transforming and selling. This mall is situated in Eskilstuna Municipality in Södermanl and County in southeast Sweden. The mall was started in August 2015. Currently, the recycling mall is functioned in the $5000 \mathrm{~m}^{2}$ area that can be extended to $15000 \mathrm{~m}^{2}$. At present, the rentable area is $3000 \mathrm{~m}^{2}$. There are four clothes stores. The first clothes store is for high-quality second hand clothes and most of the clothes are for kids. The second store is second hand cloth store that washes and irons the clothes before selling it. The third store is owned by Stockholm based charity organization and this is a normal second hand cloth stores. The fourth store is a safety kids stores that sell second hand products and safety clothes for kids. The other Second hand Stores are for sports and bicycles, building materials, computer and electronics products, furniture and households items.

In the recycling mall, there are other facilities such as redesigning lab for the vocational training school, conference rooms, and cafeteria. A restaurant and café are under construction and are expected to be open soon. In the mall, two conference rooms are also under construction. The bigger one is for 100 guests and the smaller one for 30 guests. The conferences are hosted by internal and external clients, but the majority of conferences are hosted by internal customers. The bigger conference room is also used as an event area and at the time of the observation, a change-your-toys-event was planned to the following Saturday. The vocational school associated with recycling mall has 16 students and offers a one-year program in re-design. The students work with paper, plastic and furniture. An example of a current project that the student worked with was the design of a hotel lobby. The reverse value chain process of recycling mall is depicted in the below figure 1.

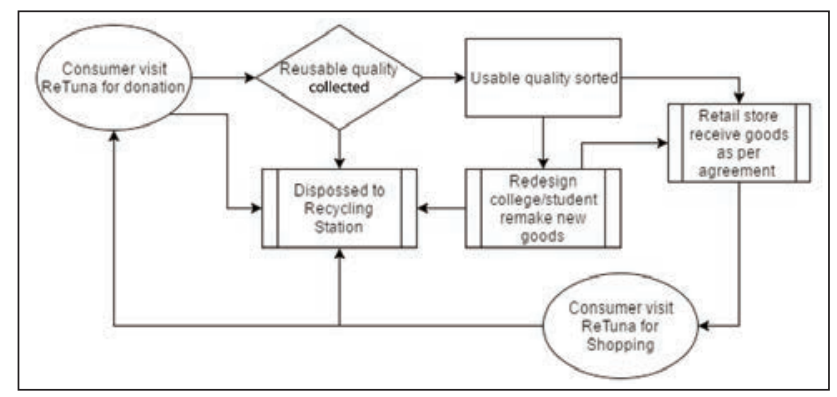

Fig. 1. Process at recycling mall

Below are the details of collection, sorting and reprocessing activities done at the recycling mall.

\section{Collection}

The mall is situated along with a waste recycling station and has a collection area on the ground floor for individual residents. The mall does not accept industrial waste. A person can drive to the mall to drop 
unwanted stuff. There are total two gates which accept the donation. A third gate is meant for different kinds of hazardous products. The gate no 2 is opened in winter while gate no 3 is for summer for all kind of items. Mall accepts all kind of items including textiles and furniture. Apart from the in-house collection, the organization has two collection bins located at waste recycling stations in Eskilstuna and Stragnas. Goods are delivered from these external collection centers once a week in peak time and once a month at low season. The stores are not allowed to receive direct donation in-store (exception-high fashion clothing store) since the mall does not want to have any trade activities and risk of black money. The high fashion clothing shop is allowed to collect items in the mall since they already had that service before they moved into the mall. It is a part of their business agreement to collect clothes. Another clothing shop tries to establish collaborations with fashion retail companies to place collection bins at their retail stores, this will able help companies to collect highquality clothes. Adjacent to the Mall, there is recycling station where one can drop all kind of waste (which cannot be reused). In total, the recycling stations are visited by around 400 cars each day. The policy of the mall is to accept all goods that an inhabitant offers for donation, but according to the mall manager, she has got information that the sorting staff in some cases tells the individual that the goods are unwanted and refer them to the waste recycling station.

\section{Sorting}

There are total six people working in the collection and warehouse and they are hired by Eskilstuna municipality. They are either physically challenged persons or suffer from another kind of disability. After receiving the donation, they sort the items in the relevant section of each shop. The Shops person then can come and sort items according to their requirements in the section, but they are not supposed to look into the unsorted donations. The Mall manager had made a list of items meant for different shops as per their agreement. Those lists are revised by the mall manager from time to time. The revision will be done in collaboration with the shops and those who work with the sorting. The school receives goods from the warehouse. The school also has a list, but in addition to this standard list, the students and teacher give a weekly list with the desired object depending on their current work. The School is offered all other goods that none of the other shops wants, an example form the observation was an old piano. Mostly textile based unique collection is offered to training schools. The students show their creativity on unwanted used items.

The inflow of goods to the sorting station varies from day to day and in some periods there are too many goods to care of for the shops. Since the flow is important due to the limited area for storage the mall offers the goods to charity organizations and different churches. The last option is disposing off to the recycling station, something that they try to avoid but sometimes it is necessary as per mall manager. In the beginning, the shops were gentle with each other and took everything that was offered. After three/four months the shops are more careful and it is a bit of competition about the goods. The clothes are first offered to the high fashion shop according to the earlier agreement. All clothes are therefore placed in their area and the staff at that shop will sort it. If it is children clothes it will be placed in the area of the kid's shops. If there are lots of clothes, the staff will not sort it piece by piece, instead, they will divide the plastic bags. At present, the recycling mall does not have data about the goods that are collected and how much goods are sorted per day. Through the sorting, the staffs of the recycling mall have started to know what kind of products each shop wants.

\section{Reprocessing}

Design laboratory for student located inside the recycling mall is the only place that is doing reprocessing or redesign activity on collected textile materials. However, children clothing shop has washing and ironing facility and the space to perform minor processing. Remaining all other shops sells collected goods without performing value addition. High fashion clothing shop washes some items at home. High fashion clothing shop also offers re-designed baby clothes and re-designed hood for strollers. One stroller hood cost between 1000-15000 SEK. The mall manager has great vision in increasing value addition on old products. On 5 years down, mall has planned to sell clothes at an average price of 300 SEK.

\section{DISCUSSION}

The reverse value chains of clothes are influenced by different factors. Paras et al. [20] have identified different factors such as business system, awareness and value creation. Some of the factors have been found relevant to the recycling mall study are discussed as follows:

Business process design: The recycling mall seems to have an excellent business plan. Facilities, as well as vision for the business, are unique and excellent. A municipality-owned company (Eskilstuna Strängnäsenergiochmiljö) owns the recycling mall. The core business for Eskilstuna Strängäsenergiochmiljö is waste management and electricity generation. The whole infrastructure is also owned by the municipality company and the recycling mall hires the area that is needed for the mall. Parts of the total area are then leased to privately owned companies such as charity organizations, social businesses and for-profit shops. The recycling mall is the facilitator for the all second hand stores. Stores are supposed to pay 1400 SEK $/ \mathrm{m}^{2}$ annually. During 2015 and 2016 there was $50 \%$ discount on rent. Beside this, shops are supposed to pay for other services on their own, for example, electricity and internet. The rent cost 
includes the space as well as second hand goods, so the shops pay for both space/area and goods.

During the first two years (2015 and 2016) the municipality gives the recycling mall a subsidy (2.5 million SEK per year) but from 2017 there was a plan to make the recycling mall economically independent. However, the mall is supposed to function by own from 2017 and will get only 50,000 SEK grant from the municipality. So they are looking for a private player like IKEA, H\&M to open recycle or reuse store in the mall. Some of the shops also offered new products, but in this case, the items have to be friendly in some way to be accepted by the mall. The newly produced products may not be a major part of the shop's assortment. Before a shop is allowed to establish in the mall, the business plan of the shop is examined and it is important that the shop has a business perspective of reuse and make a profit out of used products. In this process, the shop representative and the mall manager also discuss and agree on the kind of products the shop shall receive.

Value creation: Focus has been given to givea new look of the old and discarded product. The vocational training school is doing huge efforts to redesign old products.

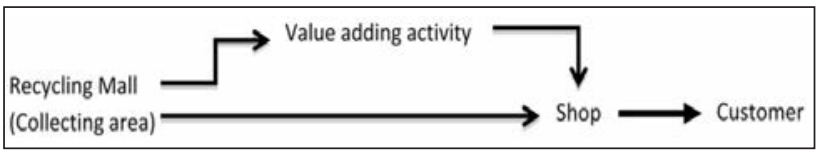

Fig. 2. The process of value addition

Value addition on the old product is a prime focus area for the mall and in the future ambition is that the shops do some value addition on the collected goods. Discarded product seems to be having zero value for consumers without any value addition. Each shop decides the price for the products they sell. At present, clothing product is sold at the average price of 100 SEK. Most of the individual donates good quality clothes. However, they are not keen on purchasing clothes from the mall. They will always criticize the price in spite the price is much lower in the mall shops.

Information: Reaching to people is the prime concern. The financial limitation is found to be the main hindrance in advertisements. Table 1 represents the methods that are followed by the mall to reach to the consumer.

Table 1

\begin{tabular}{|l|}
\hline \multicolumn{1}{|c|}{ ADVERTISEMENT METHODS } \\
\hline Local newspaper advertisement \\
Local broadcast campaigns \\
Social media like Facebook, Instagram and Twitter \\
Inviting students and other people to visit the mall \\
\hline
\end{tabular}

The advertisement is mainly focused on the consumers to raise the awareness of reuse, recycling and the mall. The advertisement budget is currently 50,000 SEK a year so most of the work is done by the mall manager. The owner company (Eskilstuna Strängnäsenerigochmiljö) has an information department that helps the mall a bit, for example with the homepage and social media, but long-term view of the department is that the mall shall manage its own business.

Initially, the mall had the campaign to invite shops in the region, but the budget for that campaign is utilized and the mall will have less money in the future for that kind of campaigns. There have been mostly positive reactions from consumers, companies in the city and other stakeholders. Individual consumers have complained that some products are missing in the mall, but negative comments have been few. The mall manager describes that when a customer visits the mall for the first time often experience a feeling of surprise. The mall manager thinks that they need to improve and expand the communication and advertisements in the future to be successful. She says that "if you shall be a real mall, people must be able to hear you."

\section{CONCLUSION}

The study shows that the recycling mall has been established near a recycling centre to promote the concept of reuse. Instead of disposing of goods to incineration, individuals are encouraged to donate the goods to the mall. The collected products are sorted on the basis of type by mall employees and kept at the different designated location of each tenant of recycling mall in line with their contract. Employees of the tenants visit the warehouse to receive and sort their assigned goods according to conditions and product categories. Some of the tenants have facilities to re-design, repair and wash the garments to improve the functionality of products. The mall management is doing efforts to increase the number of upcycling activities that the tenants perform to increase the value of the reused goods. The reuse mall also provides workshop and laboratory space to the college involved in the education of reuse and re-design. Students of the college experiment with donated goods to redesign new products. Still, redesign practice at the mall is in its initial phases, recycling mall is indeed a revolutionary concept to enhance the practice of reuse. Future research can study the scope of recycling mall across different geographical locations.

\section{ACKNOWLEDGEMENTS}

This research has been done under Erasmus Mundus joint doctoral program (SMDTex), which is financed by European Union. 


\section{REFERENCES}

[1] Paras, M.K., Pal, R., Ekwall, D., Systematic literature review to develop a conceptual framework for a reuse-based clothing value chain, In: The International Review of Retail, Distribution and Consumer Research, 2017, 1-28

[2] Dervojeda, K., et al., Clean technologies circular supply chains, In: EU report, 2014, 248-274

[3] Woolridge, A.C., et al., Life cycle assessment for reuse/recycling of donated waste textiles compared to use of virgin material: An UK energy saving perspective, In:Resources, Conservation \& Recycling, 2006, 46, 1, 94-103

[4] Farrant, L., Olsen, S.I., Wangel, A., Environmental benefits from reusing clothes, In: The International Journal of Life Cycle Assessment, 2010, 15, 7, 726-736

[5] Hawley, J.M., Digging for Diamonds: A Conceptual Framework for Understanding Reclaimed Textile Products, In: Clothing and Textiles Research Journal, 2006, 24, 3, 262-275

[6] Morley, N., Bartlett, C., McGill, I., Maximising reuse and recycling of UK clothing and textiles: $A$ report to the department for environment, Food and rural affairs, Oakdene Hollins Ltd, 2009

[7] Abraham, N., The apparel aftermarket in India-a case study focusing on reverse logistics, In: Journal of Fashion Marketing and Management: An International Journal, 2011, 15, 2, 211-227

[8] Botticello, J., Between classification, objectification, and perception: processing secondhand clothing for recycling and reuse, In: Textile, 2012, 10, 2, 164-183

[9] Ekström, K.M., Salomonson, N., Reuse and Recycling of Clothing and Textiles - A Network Approach, In: Journal of Macromarketing, 2014, 34, 3, 383-399

[10] Rogers, D.S., Tibben-Lembke, R., An examination of reverse logistics practices, In: Journal of Business Logistics, 2001, 22, 2, 129-148

[11] Cuc, S., Tripa, S., Redesign and upcycling-a solution for the competitiveness of small and medium-sized enterprises in the clothing industry, In: Industria Textila, 2018, 69, 1, 31-36, https://doi.org/10.35530/IT.069.01.1417

[12] Besiou, M., Georgiadis, P, Van Wassenhove, L.N., Official recycling and scavengers: Symbiotic or conflicting? In: European Journal of Operational Research, 2012, 218, 2, 563-576

[13] Tojo, N., et al., Prevention of Textile Waste - Material flows of textiles in three Nordic countries and suggestions on policy instruments, In: TemaNord 2012, Nordic Council of Ministers: Copenhagen

[14] Chan, T.Y., Wong, C.W.Y., The consumption side of sustainable fashion supply chain, In: Journal of Fashion Marketing and Management: An International Journal, 2012, 16, 2, 193-215

[15] Min, H., Ko, C.S., Ko, H.J., The spatial and temporal consolidation of returned products in a closed-loop supply chain network, In: Computers \& Industrial Engineering, 2006, 51, 2, 309-320

[16] Ha-Brookshire, J.E., Hodges, N.N., Socially Responsible Consumer Behavior?: Exploring Used Clothing Donation Behavior, In: Clothing and Textiles Research Journal, 2009, 27, 3, 179-196

[17] Morgan, L.R., Birtwistle, G., An investigation of young fashion consumers' disposal habits, In: International journal of consumer studies, 2009, 33, 2, 190-198

[18] Goldsmith, D., The Worn, the torn, the wearable: Textile recycling in union square, In: Nordic Textile Journal, 2012, 1, 16-29

[19] Jayaraman, V., Ross, A.D., Agarwal, A., Role of information technology and collaboration in reverse logistics supply chains, In: International Journal of Logistics: Research and Applications, 2008, 11, 6, 409-425

[20] Paras, M.K., et al., An Exploratory Study of Swedish Charities to Develop a Model for the Reuse-Based Clothing Value Chain, In: Sustainability, 2018, 10, 4, 1176

[21] Moise, M., The importance of reverse logistics for retail activity, In: The Amfiteatru Economic journal, 2008, 10, 24, 192-209

[22] Paras, M.K., Curteza, A., Revisiting upcycling phenomena: a concept in clothing industry, In: Research Journal of Textile and Apparel, 2018, 22, 1, 46-58

[23] Paras, M.K., Pal, R., Application of Markov chain for LCA: A study on the clothes 'reuse' in Nordic countries, In: Int. J. Adv. Manuf. Technol., 2018, 94, 191-201

[24] Yin, R.K., Case study research: Design and methods, SAGE publications, 2013

[25] Czarniawska, B., Social Science Research: From Field to Desk, SAGE Publications, 2014

\section{Authors:}

\section{MANOJ KUMAR PARAS ${ }^{1,2,3}$, LARS HEDEGÅRD ${ }^{3}$, ANTONELA CURTEZA ${ }^{2}$ RUDRAJEET PAL ${ }^{3}$, YAN CHEN ${ }^{1}$, LICHUAN WANG ${ }^{1}$}

${ }^{1}$ College of Textile and Clothing Engineering, Soochow University, Suzhou 215006, China

2"Gheorghe Asachi" Technical University of lasi, Bulevardul Profesor Dimitrie Mangeron 67, lasi, 700050, Romania

${ }^{3}$ Faculty of Textiles, Engineering and Business, University of Borås, Allégatan 1, 50139032 Borås, Sweden

\section{Corresponding author:}

LICHUAN WANG

e-mail: Lcwang@suda.edu.cn 